\title{
The Effect of Maternal Starvation on Plasma Insulin-Like Growth Factor I Concentrations in the Late Gestation Ovine Fetus
}

\author{
N. S. BASSETT, M. H. OLIVER, B. H. BREIER, AND P. D. GLUCKMAN \\ Developmental Physiology Laboratory, Paediatrics Department, School of Medicine, University of Auckland, \\ Auckland, New Zealand
}

\begin{abstract}
In view of the suggested relationship between substrate availability, fetal growth and circulating fetal IGF-I concentrations, we investigated the effect of maternal starvation on plasma IGF-I levels in the late gestation ovine fetus. Ten fetuses aged 125-130 d gestation were sampled daily from indwelling arterial catheters. Ewes were starved for $72 \mathrm{~h}$. Starvation was terminated with an intravenous infusion of $\mathbf{1 0 \%}$ glucose to the ewe. Food was then replaced $4 \mathrm{~h}$ later. Fetal IGF-I concentrations fell from $176.1 \pm 15.2 \mathrm{ng} / \mathrm{mL}$ before starvation to $124.5 \pm 10.3$ $\mathrm{ng} / \mathrm{mL}$ after $72 \mathrm{~h}$ starvation $(p<0.05, n=10)$. The fall in IGF-I concentrations was reversed by $4 \mathrm{~h}$ of maternal glucose infusion. In five fetuses, where samples were obtained $24 \mathrm{~h}$ after terminating the starvation, fetal IGF-I concentrations were comparable to those seen before starvation $(180.0 \pm 37.7 \mathrm{ng} / \mathrm{mL})$. This study demonstrates that acute maternal starvation causes a reversible decrease in fetal plasma IGF-I levels. These studies suggest that nutrient and in particular glucose availability is a significant determinant of fetal IGF-I secretion and support the hypothesis that IGF-I may play a role in the regulation of fetal growth. (Pediatr Res 27: 401-404, 1990)
\end{abstract}

\section{Abbreviations}

GH, growth hormone

The role of IGF in fetal life remains speculative. However, limited evidence suggests that IGF-I may have an important role in the regulation of fetal growth. IGF-I levels in umbilical cord blood at delivery have been shown to correlate with birth wt in a number of species including the rat $(1,2)$, rabbit (3), sheep (4), cow (5), and man (6-8). Studies in the fetal guinea pig (9) and fetal sheep $(10,11)$ have demonstrated that chronic alterations in placental function leading to fetal growth retardation result in decreases in fetal IGF-I levels. Such studies suggest that substrate availability may play a role in regulating fetal IGF-I secretion and that IGF-I may be an endocrine regulator of fetal growth. To further elucidate the role of nutritional factors in the acute regulation of fetal IGF secretion we investigated the effects of maternal starvation and refeeding on plasma IGF-I levels in the late gestation ovine fetus.

Received September 6, 1989; accepted November 30, 1989.

Correspondence: P. D. Gluckman, Developmental Physiology Laboratory, Department of Paediatrics, School of Medicine, University of Auckland, Auckland, New Zealand.

Supported by grants from the New Zealand Medical Research Council and the National Child Health Research Foundation of New Zealand.

\section{MATERIALS AND METHODS}

Animals and surgical procedures. Romney ewes time mated with Suffolk rams provided fetuses of known gestational ages for these studies. At $125-130$ d gestation (term $=145 \pm 3 \mathrm{~d}$ ) ewes were brought into the laboratory and allowed $4-5$ to become acclimatized to laboratory conditions before undergoing surgery. Fetal vascular surgery was performed under sterile conditions using halothane anaesthetic. Vascular catheters were inserted into the fetal femoral artery and vein and into the maternal tarsal artery and vein to obtain regular blood samples. Fetus and mother were allowed $5 \mathrm{~d}$ postoperative recovery before commencing the experiment. Ewes were fed a mixture of chaffed hay, lucerne, and barley ad libitum with water freely available.

Experimental protocol. Blood samples were collected in sterile preheparinized syringes. Fetal and maternal blood samples were obtained for $2 \mathrm{~d}$ before commencing the starvation. Ewes were then starved for $72 \mathrm{~h}$ but with water ad libitum. Starvation was terminated with a maternal i.v. infusion of $10 \%$ glucose $(0.5$ $\mathrm{mL} / \mathrm{min}$ ). This was maintained for $4 \mathrm{~h}$ and then food was replaced and the ewe allowed to eat ad libitum. Glucose infusion was reduced to $2 \%(0.5 \mathrm{~mL} / \mathrm{h})$ and continued for another $12-18$ h. This approach achieved an abrupt reversal in fetal substrate deprivation. Fetal and maternal blood samples were collected simultaneously twice daily. Plasma was separated by centrifugation and frozen at $-20^{\circ} \mathrm{C}$ until assayed. This protocol was approved by the institutional Animal Ethical Committee.

Assays. Fetal and maternal plasma samples were analyzed for glucose by the glucose oxidase method using an autoanalyser (Beckman glucose analyser 2, Beckman Instruments Inc., Fullerton, CA). Fetal and maternal IGF-I concentrations were determined by RIA (12) after a modified acid ethanol extraction of the plasma. The principal modification was the addition of a cryoprecipitation step. This extraction technique has been developed and validated for fetal sheep plasma (13). In brief, $50 \mu \mathrm{L}$ of fetal serum or plasma were diluted 1:10 with $450 \mu \mathrm{L}$ of 0.01 M PBS (pH 7.6). To this $2 \mathrm{~mL}$ of acid-ethanol mixture $(87.5 \%$ absolute ethanol, $12.5 \% 2 \mathrm{~N}$ hydrochloric acid vol/vol) were added, mixed thoroughly, and allowed to stand for $30 \mathrm{~min}$ at room temperature. Samples were then centrifuged at $36000 \mathrm{rpm}$ at $4^{\circ} \mathrm{C}$ for $30 \mathrm{~min}$. Supernatants were decanted and $1 \mathrm{~mL}$ of $0.855 \mathrm{M}$ Tris base added to neutralize the $\mathrm{pH}$. Samples were then mixed and cryoprecipitation was achieved by incubation at $-20^{\circ} \mathrm{C}$ for $1 \mathrm{~h}$ before centrifugation at $3600 \mathrm{rpm}$ for $30 \mathrm{~min}$ at $4^{\circ} \mathrm{C}$. The supernatant of each sample was then decanted and analyzed for IGF-I using an antibody $(863 / 5)$ raised in New Zealand White rabbits to recombinant human $\mathrm{N}$-terminal methylated (rh-met) IGF-I. This antibody was used at a final dilution of 1:75000. The standard curve was generated from a postnatal calf serum pool. This was extracted in acid ethanol in the same manner as for fetal plasma samples. Results are expressed in ng of rh-met IGF-I (Dr. D. Burleigh, Pitman-Moore, Terre Haute, 
IL, batch 742.44). Under these conditions, both fetal and maternal plasma extracts dilute in parallel with the standard curve. The minimum detectable concentration in this assay is $0.5 \mathrm{ng} /$ $\mathrm{mL}$ with a half maximal displacement of $3 \mathrm{ng} / \mathrm{mL}$. The interassay variation is $12.8 \%$ and the intraassay variation is $8.3 \%$. This modified extraction methodology was validated by comparing results obtained in 12 maternal and 12 fetal plasma samples using both the modified extraction technique and G75 Sephadex chromatography under acid conditions (14). The results obtained by both methodologies were highly correlated $(r=0.92)$ and the slope of the linear regression was 1.14 (13).

Data analysis. Glucose and IGF-I measurements obtained for both the fetus and mother were meaned for each sampling time. Statistical differences from control values were determined by Student's $t$ test after preliminary analysis of variance. Statistical differences from the 72-h samples were determined in the same manner. Data are expressed as mean \pm SEM.

\section{RESULTS}

Maternal glucose concentrations fell from $61.7 \pm 7.4 \mathrm{mg} / \mathrm{dL}$ during the prestarvation control period to $39.6 \pm 3.9 \mathrm{mg} / \mathrm{dL}$ ( $p$ $<0.05$ ) after $72 \mathrm{~h}$ starvation (Fig. 1). Glucose concentrations were then elevated after $4 \mathrm{~h}$ of glucose infusion to $184.0 \pm 24.1$ $\mathrm{mg} / \mathrm{dL}$ and returned to normal $18-24 \mathrm{~h}$ later $(63.4 \pm 8.6 \mathrm{mg} /$ dL). Fetal plasma glucose concentrations fell from $19.4 \pm 2.0$ $\mathrm{mg} / \mathrm{dL}$ before starvation to $15.0 \pm 1.2 \mathrm{mg} / \mathrm{dL}$ after $72 \mathrm{~h}$ of maternal starvation ( $p<0.05, n=10$, Fig. 1). Fetal glucose returned to normal within $24 \mathrm{~h}$ of terminating the starvation $(21.3 \pm 2.5 \mathrm{mg} / \mathrm{dL})$.

Fetal IGF-I concentrations fell from $176.1 \pm 15.2 \mathrm{ng} / \mathrm{mL}$ before starvation to $124.5 \pm 10.3 \mathrm{ng} / \mathrm{mL}(n=10, p<0.05$, Fig. 2) after $72 \mathrm{~h}$ of starvation. After $4 \mathrm{~h}$ of maternal i.v. infusion of $10 \%$ glucose $(0.5 \mathrm{~mL} / \mathrm{min})$, fetal IGF-I concentrations had increased to $149.2 \pm 12.1 \mathrm{ng} / \mathrm{mL}$. This was significantly elevated compared to IGF-I concentrations seen at $72 \mathrm{~h}$ starvation $(p<$ 0.05 ). In five fetuses where samples were obtained $24 \mathrm{~h}$ after commencing the maternal glucose infusion fetal IGF-I, concentrations had returned to prestarvation levels $(180.0 \pm 37.7 \mathrm{ng} /$ $\mathrm{mL}$ ). When the data were expressed as a percentage change from control values, fetal IGF-I fell to $76.4 \pm 9.45 \%$ of basal values $(p<0.05)$ after $48 \mathrm{~h}$ starvation and to $73.8 \pm 9.45 \%$ of basal values $(p<0.05)$ after 72 h starvation.

\section{DISCUSSION}

The evidence suggesting that the IGF play a role in the regulation of fetal growth has remained largely indirect and inferential (15-19). Plasma IGF-I concentrations have been shown to correlate with birth size in many species (2-8). Experimentally induced fetal growth retardation in several species has been associated with decreases in fetal IGF-I concentrations. Studies in the pregnant rat (20) and guinea pig (9) have demonstrated that chronic restriction of uterine blood flow results in a decrease in fetal IGF-I concentrations. Similarly in the fetal sheep a reduction in placental size by carunclectomy also results in a decrease in fetal IGF-I levels and in fetal wt $(10,11,21)$. Such studies suggest that restrictions in fetal nutritional substrate and/ or oxygen delivery that impair fetal growth also induce a fall in plasma IGF-I. It seems likely that these two observations are causally related. However, such inferences are based on manipulation that leads to chronic alterations in nutrient supply and placental function. In contrast, our study was designed to assess the role of nutrient supply in the acute regulation of fetal IGF-I secretion.

The regulation of circulating IGF-I secretion appears to differ between fetal and postnatal life. Postnatally growth hormone is the major regulator of plasma IGF-I concentrations (22-24). In addition, starvation reduces postnatal IGF-I secretion; an effect that appears to be regulated by alterations in $\mathrm{GH}$ receptors $(25$,

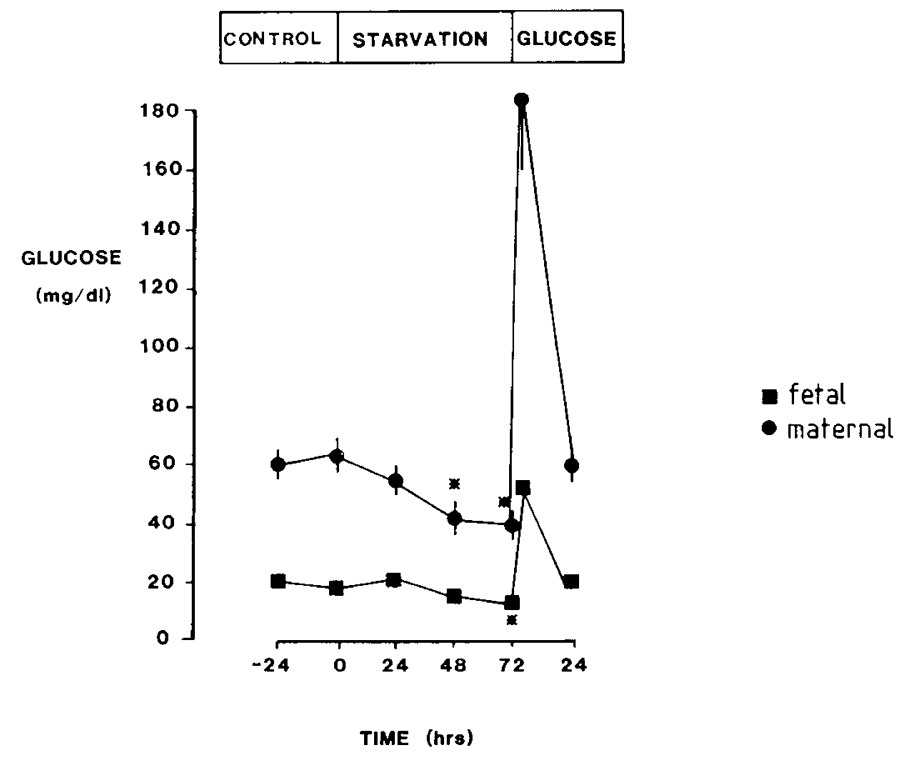

Fig. 1. Glucose concentrations in fetal and maternal plasma during maternal starvation. Mean fetal and maternal plasma glucose concentrations $( \pm$ SEM) are shown for 2 control d before starvation $(-24$ and $0 \mathrm{~h})$, then at 24,48 and $72 \mathrm{~h}$ after starvation, $4 \mathrm{~h}$ after terminating the starvation with a maternal glucose infusion $(10 \%$ glucose, $0.5 \mathrm{~mL} / \mathrm{min})$ and 24 h later $(n=10)$. Statistical significance between sample times was determined by Student's $t$ test after analysis of variance. The SEM falls within the symbols on all fetal measurements and is shown in only one direction for some points for clarity. ${ }^{*} p<0.05$

\section{\begin{tabular}{|l|l|l|}
\hline CONTROL & STARVATION & GLUCOSE \\
\hline
\end{tabular}}

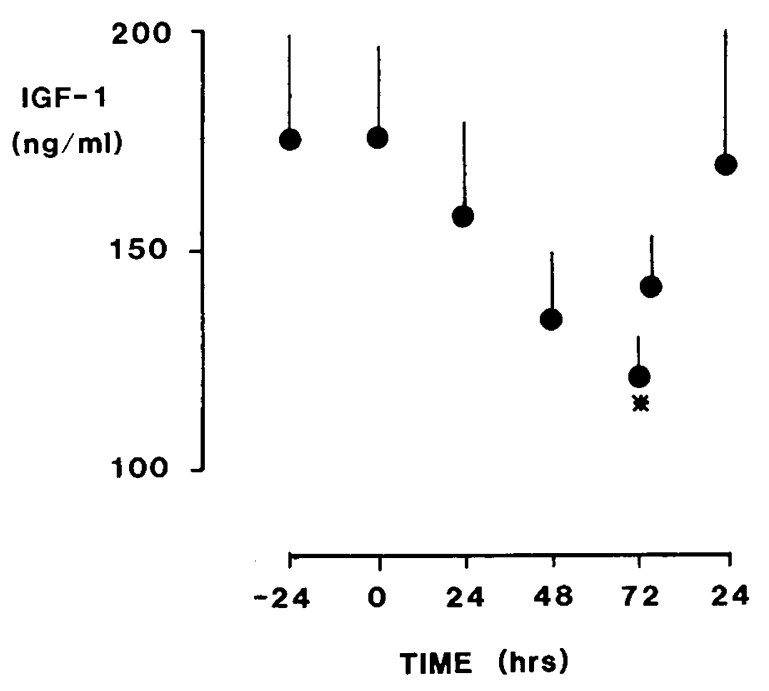

Fig. 2. Fetal plasma IGF-I concentrations during maternal starvation. Mean fetal plasma IGF-I concentrations during the study. The mean for each sample time is indicated (+SEM in one direction only). Statistical differences between sample times were determined by Student's $t$ test after analysis of variance. ${ }^{*} p<0.05$ compared to control values.

26). However, the concentration of $\mathrm{GH}$ receptors in the fetal liver are markedly reduced compared to in the postnatal sheep $(27,28)$ and growth hormone does not appear to play an important role in the regulation of fetal IGF-I release $(29,30)$. Thus, although undernutrition leads to a decrease in IGF-I levels both before and after birth it is possible that the processes involved are different. After birth at least part of the decline in plasma IGF-I associated with starvation has been associated with a loss 
of hepatic GH receptors $(25,26)$ although postreceptor mechanisms have also been implicated (31). Given the very low number of $\mathrm{GH}$ receptors in the fetus it seems unlikely that changes in $\mathrm{GH}$ receptor concentrations mediate the effect of nutrition on fetal IGF-I release.

In our study, the starvation-induced fall in plasma IGF-I was reversed by i.v. glucose infusion alone. The very rapid rise in IGF-I on refeeding may simply reflect the i.v. route of nutrient administration compared to the slower rise seen on refeeding postnatally $(25,32)$. Alternatively it may reflect a different manner in which nutrient availability affects IGF-I secretion in the fetus compared to after birth; the latter being at least partially GH dependent. Our observations suggest that fetal glucose delivery is at least one important factor in the regulation of fetal IGFI secretion. Whether such an effect of glucose is direct or is mediated via alterations in insulin release remains to be elucidated. Certainly insulin has generally been considered to be an important factor in the regulation of fetal growth. In addition, it has been suggested that its effects may be mediated through alterations in fetal IGF-I secretion $(2,19)$. Limited evidence has suggested that insulin may stimulate IGF-I release. Insulin has been reported to enhance IGF-I release by the perfused postnatal rat liver (33). Scanty data in the pig (34) and monkey (35) suggest that fetal hyperinsulinemia is associated with a slight elevation in fetal plasma IGF-I concentrations. Further, IGF-I concentrations are low at birth in infants with transient neonatal diabetes mellitus (36). In the pancreatectomized sheep fetus, IGF-I levels are low despite hyperglycemia and correlate with fetal insulin concentrations (37).

Fetal growth in late gestation is significantly affected by substrate $(17,18)$ and in particular glucose availability $(38)$. Both chronic and acute nutritional limitation to the mother impair fetal growth. The effects of chronic maternal undernutrition on fetal growth have been reported in the rat (39), sheep (40), and inferred in man from famine studies $(41,42)$. Studies in the ovine fetus have demonstrated that complete starvation of the ewe results in a marked retardation in fetal growth rate after $3 \mathrm{~d}$ (40). These effects on both fetal growth rate and IGF-I concentrations suggest a possible causal relationship. Our observations demonstrate the importance of substrate availability as an acute regulator of fetal IGF-I release and provide further indirect evidence for the hypothesis that IGF-I is a determinant of fetal growth.

\section{REFERENCES}

1. Daughaday WH, Parker KA, Borowsky S, Trivedi B, Kapadia H 1982 Measurement of somatomedin-related peptides in fetal, neonatal, and maternal rat serum by insulin-like growth factor (IGF) I radioimmunoassay, IGF-II radioreceptor assay (RRA) and multiplication-stimulating activity RRA after acid-ethanol extraction. Endocrinology 110:575-581

2. Hill DJ, Milner DRG 1981 Somatomedins and fetal growth. In: Elliot K, Whelan $\mathbf{J}$ (eds) The Fetus and Independent Life. Pitman, London, pp 124 138

3. Fletcher JM, Falconer J, Bassett JM 1982 The relationship of body and placental weight to plasma levels of insulin and other hormones during development in fetal rabbits. Diabetologia 23:124-130

4. Gluckman PD, Barry TN 1988 Insulin-like growth factors, and placental lactogen, in triplet bearing ewes and lambs. Dom Anim Endocrinol 5:209217

5. Breier BH, Gluckman PD, Bass JJ 1988 Plasma insulin-like growth factor 1 concentrations and the influence of altered nutrition in the infant calf: ontogeny and influence of altered nutrition. J Endocrinol 119:43-50

6. Ashton K, Zapf J, Einschenk I, Mackenzie IZ 1985 Insulin-like growth factors (IGF) I and II in human foetal plasma and relationship to gestational age and foetal size during mid pregnancy. Acta Endocrinol 1 10:558-563

7. Gluckman PD, Johnson-Barrett JJ, Butler JH, Edgar B, Gunn TR 1981 Studies of insulin-like growth factors -1 and -11 by specific radioligand assays in umbilical cord blood. Clin Endocrinol 19:405-413

8. Gluckman PD, Brinsmead MW 1976 Somatomedins in cord blood: relationship to gestational age and birth size. J Clin Endocrinol Metab 43:13781381

9. Jones CT, Lafeber HN, Price DA, Parer JT 1987 Studies on the growth of the fetal guinea pig. Effects of reduction in uterine blood flow on plasma sulphation-promoting activity and on the concentration of insulin-like growth factors -1 and -11 . J Dev Physiol 9:181-201

10. Jones CT, Gu W, Harding JE, Price DA, Parer JT 1988 Studies on the growth of the fetal sheep. Effects of surgical reduction in placental size, or experimental manipulation of uterine blood flow on plasma sulphation promoting activity and on the concentrations of insulin-like growth factors I and II. J Dev Physiol 10:179-189

11. Bassett NS, Gluckman PD 1987 Insulin-like growth factors in experimental fetal growth retardation in the sheep. Proc Endocrinol Soc USA 69:853(abstr)

12. Gluckman PD, Butler JH 1983 Parturition-related changes in insulin-like growth factors -1 and -11 in the perinatal lamb. J Endocrinol 99:223-232

13. Bassett NS, Breier BH 1989 Insulin-like growth factor-I in the fetal circulation: assay validation and evidence for nutritional regulation. Proc Endocrinol Soc USA 71:537(abstr)

14. Horner JM, Liu F, Hintz RL 1978 Comparison of $\mathrm{I}^{-125}$ somatomedin-C radioreceptor assays for somatomedin peptide content in whole and acid chromatographed plasma. J Clin Endocrinol Metab 47:1287-1295

15. D'Ercole AJ, Underwood LE 1981 Growth factors in fetal growth and development. In: Novy MJ, Resko JA (eds) Fetal Endocrinology. Academic Press, New York, pp 155-182

16. D'Ercole AJ, Stiles AD, Underwood LE 1984 Tissue concentrations of somatomedin C: Further evidence for multiple sites of synthesis and paracrine or autocrine mechanisms of action. Proc Natl Acad Sci USA 81:935-939

17. Gluckman PD, Liggins GC 1984 The regulation of fetal growth. In: Beard R, Nathanielsz P (eds) Fetal Physiology and Medicine. Marcel Dekker, New York, pp 511-558

18. Milner RDG, Hill DH 1984 Fetal growth control: the role of insulin and related peptides. Clin Endocrinol 21:41-43

19. Gluckman PD 1986 Hormones and fetal growth. Oxford Rev Reprod Biol $8: 1-60$

20. Vileisis RA, D'Ercole AJ 1986 Tissue and serum concentrations of somatomedin-C/insulin-like growth factor 1 in fetal rats made growth retarded by uterine artery ligation. Pediatr Res 20:126-130

21. Robinson JS, Hart IC, Kingston EJ, Jones CT, Thorburn GD 1980 Studies on the growth of the fetal sheep. The effects of reduction of placental size on hormone concentrations in fetal plasma. J Dev Physiol 2:239-248

22. Daughaday WH 1981 Growth hormone and the somatomedins. In: Daughaday WH (ed) Endocrine Control of Growth. Elsevier, New York, pp 1-24

23. Daughaday WH, Hall K, Ruben NS, Salmon WD, Van Den Brande J, Van Wyk JJ 1972 Somatomedin proposed designation for sulphation factor. Nature 234:107-108

24. Froesch ER, Schmid C, Schwander J, Zapf J 1985 Actions of the insulin-like growth factors. Annu Rev Physiol 47:443-467

25. Breier BH, Gluckman PD, Bass JJ 1987 The somatotropic axis in young steers: influence of nutritional status and oestradiol $17 \mathrm{~B}$ on hepatic high and low affinity somatotropic binding sites. J Endocrinol 116:169-177

26. Maes M, Underwood LE and Ketelslegers JM 1983 Plasma somatomedin C in fasted and refed rats: close relationship with changes in liver somatogenic but not lactogenic binding sites. J Endocrinol 97:243-252

27. Gluckman PD, Butler JH, Elliott TB 1983 The ontogeny of somatotropic binding sites in ovine hepatic membranes. Endocrinology 1 12:1607-1612

28. Freemark M, Comer M, Handwerger S 1986 Placental lactogen and GH receptors in sheep liver: striking differences in ontogeny and function. Am J Physiol 251:E328-E333

29. Gluckman PD, Butler JH 1985 Circulating insulin-like growth factor-I and -II concentrations are not dependent on pituitary influences in the mid gestation fetal sheep. J Dev Physiol 7:405-409

30. Parkes MJ, Hill DJ 1985 Lack of growth hormone-dependent somatomedins or growth retardation in hypophysectomized fetal lambs. J Endocrinol 104:193-199

31. Maes M, Underwood LE, Gerard G, Ketelslegers JM 1984 Relationship between plasma somatomedin-C and liver somatogenic binding sites in neonatal rats during malnutrition and after short and long term refeeding. Endocrinology 115:786-792

32. Isley WL, Underwood LE, Clemmons DR 1983 Dietary components that regulate serum somatomedin-C concentrations in humans. J Clin Invest $71: 175-182$

33. Daughaday WH, Phillips LS, Mueller MC 1976 The effects of insulin and growth hormone on the release of somatomedin by the isolated rat liver. Endocrinology 98:1214-1219

34. Spencer GCG, Hill DJ, Garssen GT, MacDonald AA, Colenbrander B 1983 Somatomedin activity and growth hormone levels in body fluids of the fetal pig: effects of chronic hyperinsulinemia. J Endocrinology 96:107-114

35. Susa JB, Widness JA, Hintz R, Lui F, Sehgal P, Schwartz R 1984 Somatomedins and insulin in diabetic pregnancies: effects on fetal macrosomia in the human and rhesus monkey. J Clin Endocrinol Metab 58:1099-1105

36. Blethen SL, White NW, Santiago JV, Daughaday WH 1981 Plasma somatomedins, endogenous insulin secretion and growth in transient neonatal diabetes mellitus. J Clin Endocrinol Metab 52:144-147

37. Gluckman PD, Butler JH, Comline R, Fowden A 1987 The effects of pancreatectomy on the plasma concentrations of insulin-like growth factors -1 and -2 in the sheep fetus. J Dev Physiol 9:79-88 
38. Jones CT Harding JE, Gu W Lafeber HN 1988 Placental metabolism and endocrine effects in relation to the control of fetal and placental growth. In: Kunzel W, Jensen A (eds) The Endocrine Control of the Fetus. pp 213-222

39. Pilistine SJ, Moses AC, Munro HN 1984 Placental lactogen administration reverses the effect of low-protein diet on maternal and fetal serum somatomedin levels in the pregnant rat. Proc Natl Acad Sci USA 81:5853-5857

40. Mellor DJ 1984 Investigation of fetal growth in sheep. In: Nathanielsz PW (ed)
Animal Models in Fetal Medicine, Vol IV. Perinatology Press, Ithaca, NY, pp 149-173

41. Smith CA 1947 The effects of maternal undernutrition upon the newborn infant in Holland (1944-1945). J Pediatr 30:229-243

42. Stein Z, Susser M 1975 The Dutch famine 1944-45, and the reproductive process II. Interrelations of caloric rations and six indices at birth. Pediatr Res 9:76-83

\section{Announcements}

\section{Seeking Acute Cases of Rheumatic Fever and Sydenham's Chorea}

The Child Psychiatry Branch of the National Institute of Mental Health is seeking patients for a study of the course of psychologic symptoms accompanying Sydenham's chorea and rheumatic fever. Eligible patients should have had recent (within $2 \mathrm{mo}$ ) onset of rheumatic fever, continue to have symptoms, and be at least 6 y of age. This study will rate a variety of psychologic and psychiatric symptoms and link these symptoms to anti-CNS autoantibodies. The results will be important in defining the etiology of childhood-onset psychiatric disorders. Patients and their parents will be asked to travel at NIH expense to the NIMH in Bethesda, MD for an initial interview. Brief follow-up interviews will be conducted by telephone every 2 mo for 1 y. Serum samples $(5 \mathrm{cc})$ will be obtained on four separate occasions. There will be no expense to the patient and no remuneration. Please call Dr. Susan Swedo at (301) 496-6081 or write: Dr. S. Swedo, Child Psychiatry Branch, NIMH, Bldg. 10, Room 6N240, 9000 Rockville Pike, Bethesda, MD 20892.

\section{ANNUAL MEETINGS}

The American Pediatric Society, The Society for Pediatric Research and The Ambulatory Pediatric Association will meet May 7-11, 1990; Anaheim Hilton \& Towers and Convention Center, Anaheim, CA.

Contact: APS or SPR: Association Headquarters, 2650 Yale Blvd., S.E., Suite 104, Albuquerque, NM 87106, (505) 764-9099 or 0068. APA: Ambulatory Pediatric Association, 6728 Old McLean Village, McLean, VA 22101, (703) $556-9222$.

\section{Special Program in Nutrition for a Health Heart Developed for Grade School Children and Their Parents}

The J. David Gladstone Foundation of the University of California, San Francisco, has developed a heart healthy nutrition education curriculum for third grade students and their parents. This curriculum, called the Special Program in Nutrition (SPIN), consists of two manuals and a cookbook collection of low fat, low cholesterol recipes. The manuals contain an in-service program for teachers, 27 lessons for third grade students, seven lessons for fourth grade students, and a parents' program with 10 planned meetings.

The cost of the complete set is $\$ 35.00$; the two-volume curriculum and the cookbook may be purchased separately for $\$ 30.00$ and $\$ 10.00$, respectively. Add $6.5 \%$ California sales tax where applicable. For further information contact: The Gladstone Foundation Laboratories, 2550 23rd Street, P.O. Box 40608, San Francisco, CA $94140,(415)$ 826-7500. 